\title{
A consumer-based brand performance model for assessing brand success
}

Molinillo $^{\mathrm{a}}$, S., Ekincib, Y. and Japutra ${ }^{\mathrm{c}}$, A. (2018 - Accepted) "Consumer Based Brand Performance Model". International Journal of Market Research.

${ }^{a}$ University of Malaga, ${ }^{b}$ University of Portsmouth, ${ }^{\mathrm{c}}$ University of Western Australia 


\title{
A consumer-based brand performance model for assessing brand success
}

\begin{abstract}
The aim of this study is to introduce a Consumer-Based Brand Performance Model (CBBPM) to measure brand success. The CBBPM consists of four critical constructs - brand equity, brand trust, brand satisfaction and brand loyalty - and is applied across different product categories and brands. In total, 881 consumers participated in the survey, and a structural equation modelling approach was employed to test the research hypotheses. The findings of the study suggest that the CBBPM is valid and reliable. Brand equity is positively associated with brand satisfaction, brand trust and brand loyalty. The positive effects of brand trust and brand satisfaction on brand loyalty are supported. The study suggests that the CBBPM should be used as a strategic brand management tool to track brand performance and to compare them with competing brands.
\end{abstract}

Keywords. Brand Performance Model, Brand Equity, Brand Satisfaction, Brand Trust, Brand Loyalty 


\section{Introduction}

Business performance is the actual work or output produced by a specific unit or entity in an organisation. The term 'measurable performance' refers to the ability and processes used to quantify and control specific activities and events (Morgan 2004). Business performance measurement is one of the most important topics in the field of management because performance measurement systems are useful for assessing a firm's ability to exploit its resources and achieve the targets set for it by its owners, investors and customers. Performance measurement tools enable managers to set and monitor targets and achieve the desired performance levels (Simons 2000). As stated by De Chernatony et al. (2004, p. 28) 'business performance is strongly dependent on brand performance'. Brand performance is a relative measure of brand success (Ehrenberg et al. 2004). Moreover, brand performance measures enable brand managers to understand brand value and compare brand success across different markets (Chapman 1993).

As marketing practitioners are under pressure to demonstrate how marketing expenditure creates shareholder value, previous studies have used various financial and marketoriented brand performance metrics (e.g. sales growth, market share, return on investment, price premiums) (Doyle 2000). There is therefore no single measure that captures the depth and breadth of brand performance (De Chernatony et al. 2004). The consumer-oriented brand performance models employ measures related to consumer attitude and consumer opinion, and the financially-oriented approaches use tangible assets, past revenues and future earnings, which usually suffer from a significant margin of error. When brand managers compare the performance of their own brands with the performance of their competitors' brands, they have to estimate the competitors' financial performance values, and therefore the estimation is not always reliable. Therefore, some researchers have advocated the greater convenience of consumer-based brand performance measures (e.g. Johansson et al. 2012; Rust et al. 2004). 
The aim of this study is twofold. First, it introduces a Consumer-Based Brand Performance Model (CBBPM) consisting of four distinct measures: brand equity, brand trust, brand satisfaction and brand loyalty. This is important because previous research acknowledges the importance of consumer-based performance measures for assessing brand success and brand valuation, but there is no agreement on performance criteria and their relationship with brand loyalty. Secondly, it assesses the applicability of the CBBPM across Global Brands (GBs) and Private Labels (PLs) in the apparel and sportswear retail industries. Hence, the study contributes to the branding literature by advancing understanding of consumer-oriented performance measures.

First the study introduces a review of the literature on brand performance measurement. This is followed by the research method and the study findings. The final section discusses the theoretical and managerial implications of the study.

\section{Theoretical Background}

\subsection{Brand Performance Measurements}

The brand management field has flourished over the last decades and today appears rich in related measurement scales (Zarantonello \& Pauwels-Delassus 2016). Particularly, marketing academics have developed a wide range of brand performance measures. For instance, Romero and Yagüe (2015) highlight the interaction between brand equity and customer-based brand equity in order to assess the overall productivity of marketing. Ehrenberg et al. (2004) introduce three brand performance indicators: measures related to brand size (market share and market penetration), measures related to loyalty (e.g. purchasing per buyer, percentage buying, and percentage category purchases) and measures related to switching behaviour. De Chernatony et al. (2004) recommend three brand performance indicators in the financial services industry: brand loyalty, consumer satisfaction and brand reputation. Oliveira- 
Castro et al. (2008) suggest that the effect of brand marketing should be assessed by mixed methods using financial and consumer-oriented measures. These two types of measures are interrelated because consumer-oriented measures (e.g. consumer-based brand equity) are positively associated with financial performance measures (e.g. brand market share and revenue). Lee et al. (2008) support two types of brand performance measures: financial performance measures (e.g. sales growth, margin, market share, and return on investment) and customer-based performance measures (e.g. customer acquisition, customer maintenance, customer satisfaction, and brand awareness). Dawes (2009) suggests three consumer-based brand performance metrics: brand loyalty, brand switching and brand share. Huang and Sarigöllü (2014) recommend two types of brand performance measures: customer-oriented measures (brand knowledge) and product market performance measures (revenue premium). Luxton et al. (2015) show that brand marketing communication indirectly influences the brand's market-based performance and financial performance. The market performance measure includes five variables - quality, price premium, channel support, brand loyalty and market penetration, and the brand financial performance measure includes average annual growth rate including sales value, market share, gross margin, return on investment and return on assets. Coleman et al. (2015) suggest that service brand performance should be assessed by three internal and external measures: customers (loyalty, relative satisfaction, awareness and reputation), finance (revenue-based market share and net profit) and employees (employee satisfaction and employee loyalty).

In addition to the brand performance measures introduced by academics, commercial research organisations have developed brand performance and brand valuation models based on financial metrics and market- and/or consumer-oriented measures. For example, Forbes employs financial performance measures such as revenue and return on investment (Badenhausen 2017). Others, such as Interbrand, BrandZ, Global Top 100 Brand Corporations 
and Brand Finance Global 500, utilise financial metrics as well as expert panels, consumer surveys, comparative market analyses and marketing budgets (e.g. EquiTrend, BrandAsset Valuator, Global Brand Simplicity Index and FutureBrand). Brand performance models using consumer-oriented measures employ a wide range of variables such as brand equity, brand loyalty, brand purpose, brand experience, brand strength, and brand simplicity (see Appendix $1)$.

Among the different approaches that can be used to measure brand performance, some researchers highlight the effectiveness of consumer-based brand measures, especially when comparing a brand with its competitors, because it may be more accurate to get the consumer's opinion about a brand than to obtain the financial data associated with that brand. For example, Johansson et al. (2012) show that consumer-based brand equity performed better than financially-based brand performance measures in assessing the performance of GBs in the 2008 financial crisis. Financial metrics have proved to be inadequate for understanding marketing productivity, leading to the development and increasing use of non-financial metrics (Rust et al. 2004). Moreover, several authors have found that consumer-based brand performance measures (e.g. brand equity and brand loyalty) are associated with financial performance (e.g. Chaudhuri \& Holbrook 2001; Tsai et al. 2010). In addition, the use of surveys for current and potential customers allows companies to make comparative brand performance assessments between their own and their competitors' brands to identify the strengths and weaknesses of their brands and inform their brand positioning strategies (Chapman 1993; De Chernatony et al. 2004).

Therefore, academic studies (e.g. Christodoulides \& De Chernatony 2010; Çifci et al. 2016; Dawes 2009; De Chernatony et al. 2004) and commercial research organisations (e.g. BrandAsset Valuator, EquiTrend, the FutureBrand, and the Global Brand Simplicity Index) advocate consumer-based brand performance measures. Brand loyalty, brand equity, brand 
satisfaction and brand trust are the main drivers for consumer-based brand performance. Brand loyalty is the key construct, because it is positively associated with the firm's financial performance measures (Coleman et al. 2015; Lee et al. 2008; Luxton et al. 2015) of market share, relative price (Chaudhuri \& Holbrook 2001), sustainability of demand and future profits (Interbrand 2016). Previous research suggests that brand loyalty is strongly influenced by brand equity, brand trust, and brand satisfaction (Chaudhuri \& Holbrook 2001; Çifci et al. 2016; Gecti \& Zengi 2013; Lam \& Shankar 2014; Nam et al. 2011). Accordingly, this study proposes that the Consumer-Based Brand Performance Model (CBBPM) should include four key measures: consumer-based brand equity, brand trust, brand satisfaction and brand loyalty.

\subsection{Global Brands and Private Labels}

GBs are brands 'that have widespread regional/global awareness, availability, acceptance, and demand and are often found under the same name with consistent positioning, personality, look, and feel in major markets enabled by centrally coordinated marketing strategies and programs' (Özsomer \& Altaras 2008, p. 1). Essentially, GBs are a manufacturer's own brands distributed through its own outlets (e.g. Adidas retail stores) or other retail outlets (e.g. Foot Locker). In the apparel and sportswear market, there are many GBs in operation, such as Zara, Ralph Lauren, Chanel, Burberry, Abercrombie \& Fitch, Levi's, Lacoste, Nike and Adidas. As GBs are an essential part of the apparel and sportswear business assets, high performing brands contribute to corporate business success and brand valuation (Aaker 1991; Lee et al. 2008). For instance, Zara, which belongs to Indidex, a Spanish multinational clothing company, was listed as one of the best global brands in 2017, with an $11 \%$ increase in brand valuation to $\$ 18,573$ million (Interbrand 2017). 
Along with GBs, Private Labels (PLs) have been developed rapidly in the apparel and sportswear retail sectors in recent years (d'Astous \& Saint-Louis 2005; Herstein et al. 2013; Izquierdo-Yusta et al. 2016; Molinillo et al. 2016). PLs are a retailer's own brands, and allow the retailer to differentiate its offerings from those of competing brands and retailers (Molinillo et al. 2016). Many retail chains, such as Walmart (with labels such as George, NOBO, Simply Basic, Faded Glory), Carrefour (Tex), Decathlon (Quechua, Domyos, Kalenji), El Corte Inglés (Emidio Tucci, Green Coast, Easy Wear), Macy's (Charter Club, Club Room, Giani Bernini), and Tesco $(\mathrm{F} \& \mathrm{~F})$, sell their private labels in their own retail stores.

According to Izquierdo-Yusta et al. (2016), the performance of GBs has suffered increasingly from competition from PLs, due to the growing internationalisation of retailers, upstream vertical integration and the increasing number of retail chains. Retailers create fashion PLs to control their supply chain, increase their brand portfolio and improve their brand image (McColl \& Moore 2011; Khan et al. 2012). Consumers choose global fashion brands to express their self-image or social identity. Also, consumers feel that purchasing GBs creates a lower social risk (i.e. acceptance by peer groups) than purchasing PLs (Liljander et al. 2009). Therefore, retailers try to convince consumers that premium PLs offer better quality products than traditional PLs, and have a similar quality to GBs (d'Astous \& Saint-Louis 2005; Herstein et al. 2013). For example, Decathlon highlights its product innovation, Walmart includes organically manufactured clothing in its portfolio, and Macy's states that its goal is to deliver exceptional value. Although there are not yet any empirical studies to explain why consumers choose PLs over GBs, PLs are used to differentiate retail stores and improve store loyalty (Corstjens \& Lal 2000; McColl \& Moore 2011). 
Despite the growing market share of PLs, research on their performance is limited. Moreover, González-Benito et al. (2015) state that the magnitude of the performance factors is likely to differ between GBs and PLs. However, to the best of our knowledge, there is no study comparing the performance of GBs and PLs from the consumer's point of view in the apparel and sportswear retail sectors.

\subsection{Development of Hypotheses}

Consumer-based brand equity $(\mathrm{CBBE})$ receives significant attention from researchers and marketing managers because brand equity is positively associated with company equity and brand success. Christodoulides and De Chernatony (2010, p. 48) refer to CBBE as 'a set of perceptions, attitudes, knowledge, and behaviours on the part of consumers that results in increased utility and allows a brand to earn greater volume or greater margins than it could without the brand name'. In this study, we treat overall CBBE as a value-oriented, image-based entity that includes key variables such as perceived quality, brand personality, brand awareness, brand identification, self-congruence and lifestyle-congruence (Çifci et al. 2016). Bloemer and Kasper (1995, p. 314) define brand satisfaction as 'the outcome of the subjective evaluation that the chosen brand meets or exceeds the expectations'. Brand trust is defined as the willingness of the average customer to rely on the brand's ability to perform its function (Chaudhuri \& Holbrook 2001).

Oliver (1999, p. 34) defines brand loyalty as a 'deeply held commitment to rebuy or repatronize a preferred product/service consistently in the future, thereby causing repetitive samebrand or same brand-set purchasing, despite situational influences and marketing efforts having the potential to cause switching behaviour'. In this research, we treat brand loyalty as an attitudinal construct that captures the consumer's intention to purchase or recommend behaviour. 
As can be seen from Figure 1, the CBBPM proposes that overall brand equity is positively associated with brand satisfaction (H1), brand trust (H2) and brand loyalty (H3). The relationship between brand equity and brand loyalty is indirect. Hence, brand trust and brand satisfaction mediate the effect of brand equity on brand loyalty. Furthermore, brand satisfaction (H4) and brand trust (H5) are positively related to brand loyalty. Figure 1 shows the CBBPM and the relationships between the four constructs.

\section{[Please, insert Figure 1 about here]}

Customer-based brand equity (CBBE) is essential for assessing brand performance and gaining competitive advantage in the marketplace (Lassar et al. 1995). Building from Aaker's (1991) and Keller's (1993) models of brand equity, Nam et al. (2011) argue that brand loyalty is one of the components of brand equity, but that it is also an outcome of other brand equity concepts. Brand equity is a conceptually broader concept, and encompasses perceived quality, brand personality, brand awareness, brand identification, self-congruence and lifestylecongruence, while brand loyalty is formed of behavioural intentions (e.g. intention to repurchase, intention to recommend). This position is consistent with that of Keller (1998), who argues that stronger brand loyalty is one of the characteristics of a brand possessing strong brand equity. Furthermore, several researchers acknowledge a positive relationship between brand equity and brand loyalty (Molinillo et al. 2015).

Previous studies suggest that brand equity has a positive influence on brand satisfaction and brand trust. Consumers' satisfaction with a brand is dependent on both functional benefits (e.g. perceived quality, service employee competence) and symbolic benefits (e.g. brand identification, self-congruence) (Nam et al. 2011). Brand equity reflects the overall benefits 
that the consumer associates with the brand, and it has positive effects on consumers' satisfaction with the brand experience (Ekinci et al. 2008; Nam et al. 2011).

Brand trust represents consumers' feeling of security and emotional connection with a brand (Delgado-Ballester \& Munuera-Alemán 2001). Previous research indicates that brand equity directly influences brand trust. For instance, Kim (2014) finds that service quality is positively related to brand trust. Han et al. (2015) show that brand affect, brand awareness, and self-congruence are antecedents to brand trust. Phan and Ghantous (2013) show that brand trust strongly mediates the impact of brand association on loyalty in the banking industry. Hence we propose that:

H1. Brand equity has a positive relationship with brand satisfaction.

H2. Brand equity has a positive relationship with brand trust.

H3. Brand equity has a positive relationship with brand loyalty.

Brand loyalty is positively affected by brand satisfaction (Nam et al. 2011). Overall, there is a positive relationship between customer satisfaction and loyalty intentions (Kumar et al. 2013). Satisfied consumers generally want to continue using the same brand in the future. Previous studies support the existence of a positive relationship between brand satisfaction and brand loyalty in service industries. Nam et al. (2011) show the positive effects of consumer satisfaction on brand loyalty in the hotel and restaurant industry. Miquel-Romero et al. (2014) find that private label satisfaction has a direct, positive impact on private label loyalty in convenience goods. Çifci et al. (2016) demonstrate the positive effect of brand satisfaction on brand loyalty in the fashion retail industry in Turkey and Spain. Further empirical evidence for the positive relationship between brand satisfaction and brand loyalty can be found in Ekinci et al. (2008) and Kuikka and Laukkanen (2012), among others. 
However, brand satisfaction is not enough to explain loyalty (Kumar et al. 2013; Oliver 1999). Brand trust is another important antecedent of brand loyalty (Chaudhuri \& Holbrook 2001; Lam \& Shankar 2014). A customer trusts a brand when the brand meets the customer's expectations. The continuing fulfilment of promises is one of the most important motivations in developing a long-term relationship with a brand (Delgado-Ballester \& Munuera-Alemán 2001). Scholars have empirically demonstrated the positive influences of brand trust on brand loyalty. For instance, Lam and Shankar (2014) show that consumers' brand loyalty for smartphones strongly depends on brand trust. Kuikka and Laukkanen (2012) find that brand trust is a significant factor for brand attitudinal loyalty within the chocolate market. Gecti and Zengi (2013) demonstrate that brand trust is positively related to both attitudinal loyalty and behavioural loyalty to sports shoes. The positive influence of brand trust on brand loyalty has also been found to be significant in a business-to-business context (Alwi et al. 2016). Accordingly, the model proposes two research hypotheses with regards to the relationships between brand loyalty, brand satisfaction and brand trust:

H4. Brand satisfaction has a positive relationship with brand loyalty.

H5. Brand trust has a positive relationship with brand loyalty.

\section{Method}

Two surveys were conducted in Spain, where a Spanish marketing research company helped to collect the data. In total, 435 respondents participated in the Global Brands (GB) survey and 446 respondents participated in the Private Labels (PL) survey. At the beginning, respondents were asked to think about brands in either the fashion or the sportswear category. Afterwards, in each survey the respondents were given a list of 30 different fashion/sportswear 
GBs and PLs. These brands were chosen taking into account international brand rankings such as Interbrand Best Global Brand, Interbrand Best Retail Brand, L2 Digital IQ Index of Fashion and L2 Digital IQ Index of Sportswear, as well as the presence of the brands in the Spanish market. The respondents were asked to choose from the list a brand with which they were familiar. The brand performance measures were adapted from previous studies. Details of the indicators and factor loadings can be seen in Appendix 2.

For the GB survey, most of the respondents were female $(56.8 \%)$ and under 45 years old (55.2\%). Their level of education was mostly an undergraduate degree (40.7\%). For the PL survey, most of the respondents were female (52.9\%) and under 45 years old (52.9\%). Their level of education was mostly an undergraduate degree (38.2\%).

\section{Findings}

Normality tests were conducted based on the skewness and kurtosis values of each item. The distribution of the data is normal since the skewness and kurtosis values were around the absolute values of -1 and +1 (Hair et al. 2006). After checking for normality, the data were checked to discover whether or not common-method variance posed a threat. This was done using Harman's single-factor test (Podsakoff et al. 2003). Common-method variance poses a threat if a single unrotated factor solution appears from the exploratory factor analysis test or if

one general factor accounts for the majority of the covariance among the measures. The GB data revealed three factors with Eigen values greater than 1, accounting for $72.17 \%$ of the total variance, whereas the PL data also revealed three factors with Eigen values greater than 1, accounting for $61.59 \%$ of the total variance. These results suggest that common-method variance does not pose a significant threat. Next, two measurement models were created. Table 1 displays the fit statistics of both measurement models. 


\section{[Please insert Table 1 about here]}

Based on the results, both of the measurement models produced a good fit. After confirming the model fit, the validity and reliability of the constructs were checked. Table 2 displays the Cronbach's Alpha ( $\alpha$ ) values, the average variance extracted (AVE) values and the correlations.

\section{[Please insert Table 2 about here]}

As can be seen from Table 2, all of the constructs are reliable since the $\alpha$ values are above the 0.60 threshold (Malhotra 2010). Following Fornell and Larcker (1981), from the AVE values it can be concluded that these constructs achieve discriminant validity, since the AVE values are above the squared inter-correlations. To test the research hypotheses, two structural models were created. Table 3 displays the fit statistics of the structural models.

\section{[Please insert Table 3 about here]}

The results of the fit statistics show that the two structural models produced a good fit. Afterwards, the research hypotheses were tested. In addition, the data were categorised into sportswear and apparel brands for both GBs and PLs. For GBs, the brands that were categorised as sportswear were Adidas, Camper, Levi's, New Balance, Nike, Puma, Quiksilver, Reebok, The North Face, Timberland, and Vans. For PLs, the brands that were categorised as sportswear were Artengo, Boomerang, Domyos, Kalenji, Kipsta, Polinesia, Quechua, Tenth, Tribord, and Wed'ze. Table 4 displays the results of the testing of the hypotheses. 


\section{[Please insert Table 4 about here]}

Based on the results from testing the hypotheses, all five of the research hypotheses were supported. Hence CBBE has a positive influence on brand satisfaction (H1), brand trust (H2) and brand loyalty (H3). Brand satisfaction and brand trust positively influence brand loyalty (H4 and H5), as expected. However, it should be acknowledged that the standardised path coefficients (SPCs) of the GB data were greater than the SPCs of the PL data, except for the link between brand satisfaction and brand loyalty, where the SPC was greater for the PL data.

Next, the research hypotheses for both the GB and the PL data were tested for each category (i.e. sportswear and apparel). For GBs, all of the research hypotheses were supported. However, it should be acknowledged that the SPCs for the sportswear data were greater than the SPCs for the apparel data, except with respect to the link between brand trust and brand loyalty. For PLs, all of the research hypotheses were also supported. By contrast, for PLs, the SPCs for the apparel data were greater than the SPCs for the sportswear data, except with respect to the link between brand trust and brand loyalty.

In order to confirm whether there are significant differences between the constructs for GBs and PLs, an independent samples t-test was conducted. The scores of each of the constructs were summed. Table 5 displays the results of the independent samples t-test.

\section{[Please insert Table 5 about here]}

Interestingly, the results show that PLs perform better than GBs on our brand performance model, particularly for brand equity, brand satisfaction, and brand trust. However, 
we did not find any differences in terms of consumers' brand loyalty between the GB and the PL data.

The differences between sportswear and apparel were then analysed for each of the GB and the PL data. For GBs, the sportswear category performs better than the apparel category in terms of brand equity and brand satisfaction. We did not find any differences between the two categories in terms of brand trust and brand loyalty. For PLs, the apparel category performs better than the sportswear category on each construct (brand equity, brand satisfaction, and brand loyalty), except brand trust. We did not find any differences between the two categories in terms of brand trust.

\section{Conclusions}

This study introduces a Consumer-Based Brand Performance Model (CBBPM) to measure brand success. The results of the study show that brand equity, brand satisfaction and brand trust are prominent variables in explaining brand loyalty - an important construct for a firm's success (e.g. Coleman et al. 2015; Ekinci et al. 2008; Luxton et al. 2015; Nam et al. 2011). These three constructs explain 68\% (GBs) and 61\% (PLs) of the variance in brand loyalty.

The CBBPM is interesting for researchers and practitioners beyond the apparel and sportswear industries. First, in comparison to other brand performance measures, it has the advantages of a parsimonious model with only four constructs, which are among the brandrelated variables with most consumer behaviour predictive power (Zarantonello \& PauwelsDelassus 2016). Brand equity reflects the importance, value and incremental utility that brands have for consumers. This concept has been validated by the literature and applied to products of different natures (e.g. food, beverages, household equipment, luxury goods, transport services, catering and accommodation, tourist destinations). Brand satisfaction represents the 
result of consumers' experiences with the brand in both functional and symbolic dimensions. Therefore, it plays an important role in the construction of strong brands in the long term, regardless of the product category. Similarly, brand trust is a key variable for building longterm relationships between consumers and brands, and its positive influence has been found to cross product categories and brands in previous studies. Finally, the achievement of strong brand loyalty is one of the best outcomes to which a brand in any industry might aspire. Loyalty reflects the positive attitude of the consumer to continue purchasing and recommending a brand. It is a key construct that has been used in recent decades to show the success of brands in all product categories. Therefore, if all model variables have been positively associated with brand performance across product categories and brands, we can assert that the model presented in this study has a wide scope, which extends beyond the industries in which it has been validated.

Second, although the CBBPM has only been validated in two industries (i.e. apparel and sportswear retailing), we argue that it also has relevance in other contexts. These days, it is common to see global fashion brands expand into other categories. For instance, we see that Zara created Zara Home, which focuses on houseware. Armani, an Italian fashion brand, created Armani/Dolci, which sells chocolates, jams, jellies, pralines and so forth. On the other hand, other brand categories have also branched out into the fashion industry. For instance, Porsche created Porsche Design that is not only in the fashion business but also deals in categories such as electronics. These examples show that brands are focussed on the consumer's lifestyle, supporting the generalizability of our CBBPM.

Moreover, previous research states that brand performance in consumer markets tends to be evenly distributed (e.g. Dawes, 2009; Fennell et al., 2003). The argument that supports this notion is that the buyers of one brand also buy other brands (Dawes, 2008). For instance, one could argue that the people who purchase Gucci are the same people who purchase Ferrari and/or Cartier. Dawes (2009) shows that consumer brands exhibit polygamous loyalty, with the 
sharing of customer purchases with other brands fairly in line with the market share of those other competitor brands, and approximately equal performance levels among demographic subgroups.

Regarding the comparison of GBs and PLs brand performance, we find that for GBs, brand trust and brand equity are more important in building brand loyalty, whereas for PLs, brand trust and brand satisfaction are more important. Looking at the mean scores of this study, PLs perform better than GBs on the three brand performance measures. Hence, our study confirms that even after the recent time of economic hardship has passed, PLs perform better than GBs. These findings support Deloitte's (2015) study, which states that consumers see PLs as genuine alternatives to GBs. This result might be explained by the fact that PLs have improved their perceived image of quality through premium product lines (ter Braak et al. 2014). Global brand managers should pay attention to this development as PLs could seriously challenge their market share.

\section{Managerial implications}

By tracking the performance of their brands, managers can prioritize their efforts and allocate their resources more efficiently in order to improve brand loyalty over time (Zarantonelo \& Pauwels-Delassus 2016). Using our CBBPM, we argue that managers could track the development of their brands and evaluate their long-term performance. In order to implement CBBPM, brand managers should focus on brand equity, brand trust and brand satisfaction to increase brand loyalty. Given the simplicity of the measures, managers might easily integrate this model into tracking studies (e.g. online surveys, computer-assisted interviewing, panel data) to monitor brand performance. They could develop internal and external benchmarks to assess and track brand performance over time or over a specific period. Managers could also use our measures to evaluate the position of their brands relative to their 
competitors, as well as to compare brand performance. Managers will be able to evaluate the efficacy of marketing programmes by determining which activities contribute to building or harming brand performance and thus be able to decide whether they should be discontinued. Moreover, its predictive capability allows managers to evaluate the brand not only in terms of the customer-brand relationship but also in financial terms by estimating repurchasing intention and therefore financial return.

Focussing on the CBBPM measures, the overall CBBE construct makes the model more useful, for example, in the assessment of the impact on brand performance of strategies such as brand extension or co-branding by measuring the equity of the co-brands and the parent brand before and after the brand extension. The model could also be used, for example, to assess the impact of a negative event or an unexpected problem, which might harm brand credibility, on the brand's performance in sectors as diverse as food or automotive. It seems that consumers these days are more interested in whether brands are trustworthy, pay attention to their interests and do not take advantage of them. Thus, brand managers should put more effort into developing affective relationships between brands and consumers. For instance, brand managers could develop online brand communities, foster social networking practices or organise events that cater for the hobbies or interests of their target markets. Subsequently, managers could focus on their brand's transparency and social responsibility. According to Kang and Hustvedt (2014), increasing consumers' perception of transparency and social responsibility leads to higher trust in the company. Brand managers should invest more in creating sustainable business practices. Companies should communicate that they care not only for their consumers but also for their employees, the community and the ecological and social environment. In regard to brand satisfaction, managers should encourage customers to closely evaluate their brands because, if the results manifest satisfaction, the effect on brand loyalty will be positive. 
The results imply that to enjoy the substantial competitive and economic advantages provided by a loyal customer base (e.g. low price sensitivity, brand advocacy, better revenue forecasting), managers should focus on CBBE, brand satisfaction and brand trust. Truly loyal customers perceive good brand value, are manifestly satisfied with the brand and rely on it. Through brand loyalty, the CBBPM can also be useful to assess the value of the brand for licensing or sales purposes, or to evaluate the impact of marketing activities such as communications campaigns.

Finally, regarding the comparison of GBs and PLs, although for GBs brand equity is more important than brand satisfaction in building brand loyalty, and the opposite is true for PLs, brand equity and brand satisfaction are key measures for improving brand loyalty. Thus, it is always good for managers to increase brand equity by focusing on the brand's functional (i.e. quality) and symbolic (i.e. brand personality) features. Brands could offer a longer warranty to increase perceived quality. As for brand satisfaction, brand managers should understand that this is not always related to the tangible aspects of the brand but is also related to the service that surrounds the brand. For example, brands should make sure that they deliver the brand in time as promised. Brands could also increase the value of their products by cooperating with other organisations of interest to their consumers. For instance, if consumers purchase training shoes from Nike, they might be entitled to a discount when they visit a recreational park.

This study introduces a consumer-based brand performance model based on data from two different surveys. It has some limitations. The respondents had similar demographic profiles and hence it would be worthwhile to compare the performance of GBs and PLs with the same respondents. It would also be interesting to measure and track the performance of GBs and PLs over a period of time. A longitudinal study would help to explain whether the performance of PLs is, in fact, better than the performance of GBs. In order to increase the value of the CBBPM, future studies should investigate the relationships between it and 
marketing performance matrices (e.g. profitability). Another limitation is that this study was conducted with only two categories (i.e. apparel and sportswear). Although previous research argues that brand performance in consumer markets is evenly distributed (e.g. Dawes, 2009; Fennell et al., 2003), further study should test the CBBPM in other contexts to increase its generalizability. Finally, it would be interesting to include some moderating variables into the analysis, such as retailer loyalty and price sensitivity. 
Appendix 1. Brand performance measures used by commercial research organisations

\begin{tabular}{|c|c|c|}
\hline Measure & Methodology & Key components \\
\hline $\begin{array}{l}\text { BrandZ: Top } 100 \\
\text { Most Valuable Global } \\
\text { Brands } \\
\text { (Millward Brown } \\
\text { 2014). }\end{array}$ & $\begin{array}{l}\text { Covers two million consumers and more } \\
\text { than } 10,000 \text { different brands in over } 30 \\
\text { countries. Combines ongoing consumer } \\
\text { research with financial analysis. }\end{array}$ & $\begin{array}{l}\text { Financial value, brand } \\
\text { contribution and brand } \\
\text { value. }\end{array}$ \\
\hline $\begin{array}{l}\text { Interbrand: Best } \\
\text { Global Brand } \\
\text { (Interbrand 2016). }\end{array}$ & $\begin{array}{l}\text { Brand valuation brings together market, } \\
\text { brand, competitor and financial data. It uses } \\
\text { several information sources such as expert } \\
\text { panel assessment, desk research, financial } \\
\text { data from annual reports, consumer goods } \\
\text { data and social media analysis. }\end{array}$ & $\begin{array}{l}\text { Financial performance, } \\
\text { role of brand in purchasing } \\
\text { decisions, brand strength } \\
\text { and brand value. }\end{array}$ \\
\hline $\begin{array}{l}\text { Forbes: The World's } \\
\text { Most Valuable Brands } \\
\text { (Badenhausen 2017) }\end{array}$ & Values brands using only financial variables. & Financial brand value. \\
\hline $\begin{array}{l}\text { Global Top } 100 \text { Brand } \\
\text { Corporations } \\
\text { (European Brand } \\
\text { Institute 2017). }\end{array}$ & $\begin{array}{l}\text { Calculation of brand value is based on } \\
\text { financial data in six steps. }\end{array}$ & $\begin{array}{l}\text { Brand strength, financial } \\
\text { analysis, cash flows, } \\
\text { brand-specific discount } \\
\text { rate and brand value. }\end{array}$ \\
\hline FutureBrand Index & $\begin{array}{l}\text { Based on the views of an informed global } \\
\text { public: they know about the companies in } \\
\text { question, and are in professional jobs - they } \\
\text { include top leaders and managers. } \\
\text { Respondents }(3,000) \text { from } 17 \text { countries. }\end{array}$ & $\begin{array}{l}\text { Brand purpose, brand } \\
\text { experience and future } \\
\text { brand. }\end{array}$ \\
\hline $\begin{array}{l}\text { Brand Finance Global } \\
500 \text { (Brand Finance } \\
\text { 2017) }\end{array}$ & $\begin{array}{l}\text { Calculates the value of the brand in seven } \\
\text { steps based on consumer surveys. }\end{array}$ & $\begin{array}{l}\text { Brand strength index, } \\
\text { brand royalty rate, brand } \\
\text { revenues, brand value. }\end{array}$ \\
\hline $\begin{array}{l}\text { BrandAsset Valuator } \\
\text { (Young \& Rubicam } \\
\text { 2017) }\end{array}$ & $\begin{array}{l}\text { Measures consumer perception of a brand } \\
\text { based on two criteria: 1) brand strength in } \\
\text { terms of differentiation and relevance; and } \\
\text { 2) brand stature as a combination of } \\
\text { consumers' esteem and knowledge. Brand } \\
\text { strength reflects future growth potential. } \\
\text { Brand stature reflects current operating } \\
\text { value. }\end{array}$ & $\begin{array}{l}\text { Brand strength and brand } \\
\text { stature. }\end{array}$ \\
\hline $\begin{array}{l}\text { Global Brand } \\
\text { Simplicity Index } \\
\text { (Siegel Plus Gale, } \\
\text { 2017) }\end{array}$ & $\begin{array}{l}\text { Based on an online user/non-user survey } \\
\text { with more than } 14,000 \text { respondents in } 9 \\
\text { countries. }\end{array}$ & Brand simplicity. \\
\hline $\begin{array}{l}\text { EquiTrend. Brand of } \\
\text { the Year } 2017 \\
\text { (The Harris Poll 2017) }\end{array}$ & $\begin{array}{l}\text { Based on a sample of US consumers } \\
\text { surveyed online about a total of } 40 \text { randomly } \\
\text { selected brands out of } 3,000 \text { brands in } 300 \\
\text { categories. }\end{array}$ & $\begin{array}{l}\text { Brand familiarity, brand } \\
\text { quality, brand } \\
\text { consideration, brand } \\
\text { accessibility, brand } \\
\text { attraction, brand } \\
\text { attachment and induced } \\
\text { action. }\end{array}$ \\
\hline
\end{tabular}


Appendix 2. Measurement scales

Overall Consumer-Based Brand Equity (Yoo \& Donthu, 2001)

(7-point: 1 = Strongly Disagree - 7 = Strongly Agree)

Standardized path coefficients

GBs PLs

$\begin{array}{lll}\text { It makes sense to buy this brand instead of any other, even if they } & 0.84 & 0.75\end{array}$

are the same.

$\begin{array}{lll}\text { Even if another fashion or sportswear brand has the same features } & 0.91 & 0.85\end{array}$

as this brand, I would prefer to buy this brand.

$\begin{array}{lll}\text { If there is another fashion or sportswear brand as good as this brand, } & 0.88 & 0.92\end{array}$

I prefer to buy this brand.

$\begin{array}{llll}\text { If another fashion or sportswear brand is not different from this } & 0.80 & 0.78\end{array}$

brand in any way, it seems smarter to purchase this brand.

Brand Satisfaction (Spreng \& Mackoy 1996)

(7-point)

Dissatisfied - Satisfied

GBs PLs

Worse than expected - Better than expected

$0.76 \quad 0.72$

$\begin{array}{llll}\text { Worse than other brands purchased - Better than other brands } & 0.88 & 0.68\end{array}$

purchased

$\begin{array}{lll}\text { Terrible - Delighted } & 0.92 & 0.79\end{array}$

Extremely poor value of money - Extremely good value of money $\quad 0.85 \quad 0.67$

Brand Trust (Lassar et al. 1995)

(7-point: 1 = Strongly Disagree -7 = Strongly Agree)

GBs PLs

$\begin{array}{lll}\text { I consider the company and people who stand behind this brand to } & 0.84 & 0.64\end{array}$

be very trustworthy.

$\begin{array}{llll}\text { In regard to consumer interests, this company seems to be very } & 0.87 & 0.84\end{array}$

caring.

$\begin{array}{llll}\text { I believe that this company does not take advantage of consumers. } & 0.68 & 0.59\end{array}$

Brand Loyalty (Çifci et al. 2016)

(7-point: 1 = Strongly Disagree $-7=$ Strongly Agree)

GBs PLs

$\begin{array}{llll}\text { I will recommend this brand to someone who seeks my } & 0.87 & 0.91\end{array}$

advice.

$\begin{array}{lll}\text { Next time I will purchase a clothing item from this brand. } & 0.78 & 0.80\end{array}$

$\begin{array}{lll}\text { Even if another fashion or sportswear brand offers more } & 0.63 & 0.39\end{array}$

attractive prices, I will continue to purchase this brand's

products. 


\section{REFERENCES}

Aaker, D. (1991) Managing brand equity. New York: Free Press.

Alwi, S. F. S., Nguyen, B., Melewar, T. C., Loh, Y. H. \& Liu, M. (2016) Explicating industrial brand equity: Integrating brand trust, brand performance and industrial brand image. Industrial Management \& Data Systems, 116, 5, pp. 858-882.

Badenhausen, K. (2017) Forbes. The World's Most Valuable Brands 2017: By The Numbers. Retrieved from: https://www.forbes.com/sites/kurtbadenhausen/2017/05/23/theworlds-most-valuable-brands-2017-by-the-numbers/\#21d668e7303d

(Access 20/10/2017)

Bloemer, J. \& Kasper, H. (1995) The complex relationship between consumer satisfaction and brand loyalty. Journal of Economic Psychology, 16, 2, pp. 311-29.

Brand Finance (2017) Brand Finance Global 500 2017. Retrieved from: http://brandfinance.com/knowledge-centre/reports/brand-finance-global-500-2017/ (Access 20/10/2017)

Chaudhuri, A. \& Holbrook, M. B. (2001) The chain of effects from brand trust and brand affect to brand performance: the role of brand loyalty. Journal of Marketing, 65, 2, pp. 81-93.

Christodoulides, G. \& De Chernatony, L. (2010) Consumer-based brand equity conceptualization and measurement: A literature review. International Journal of Research in Marketing, 52, 1, pp. 43-66.

Çifci, S., Ekinci, Y., Whyatt, G., Japutra, A., Molinillo, S. \& Siala, H. (2016). A cross validation of Consumer-Based Brand Equity CBBE): Driving customer equity in retail brands. Journal of Business Research. 69, pp. 3740-3747

Coleman, D. A., de Chernatony, L. \& Christodoulides, G. (2015) B2B service brand identity and brand performance: an empirical investigation in the UK's B2B IT services sector. European Journal of Marketing, 49, 7/8, pp.1139-1162. 
Corstjens, M. \& Lal, R. (2000) Building store loyalty through store brands. Journal of Marketing Research, 37, 3, pp. 281-291.

d'Astous, A. \& Saint-Louis, O. (2005) National versus store brand effects on consumer evaluation of a garment. Journal of Fashion Marketing and Management: An International Journal, 9, 3, pp. 306-317.

Dawes, J. G. (2009) Brand Loyalty in the U.K. Sportswear Market. International Journal of Market Research, 51, 4, pp. 449-463.

Dawes, J. (2008). Regularities in buyer behaviour and brand performance: The case of Australian beer. Journal of Brand Management, 15(3), 198-208.

De Chernatony, L., Harris, F. \& Christodoulides, G. (2004) Developing a brand performance measure for financial services brands. The Service Industries Journal, 24, 2, 15-33.

Delgado-Ballester, E. \& Luis Munuera-Alemán, J. (2001) Brand trust in the context of consumer loyalty. European Journal of Marketing, 35, 11/12, pp. 1238-1258.

Deloitte (2015) The 2015 American Pantry Study. The call to re-connect with consumers. https://www2.deloitte.com/content/dam/Deloitte/us/Documents/consumer-business/uscb-2015-american-pantry-study.pdf (accessed 01.11.16)

Doyle, P. (2000) Value-Based Marketing. Chichester: John Wiley \& Sons.

Ehrenberg, A. S., Uncles, M. D. \& Goodhardt, G. J. (2004) Understanding brand performance measures: using Dirichlet benchmarks. Journal of Business Research, 57, 12, 1307 1325 .

Ekinci, Y., Dawes, P. L. \& Massey, G. R. (2008) An extended model of the antecedents and consequences of consumer satisfaction for hospitality services. European Journal of Marketing, 42, 1/2, pp. 35-68.

European Brand Institute (2017) Global Top 100 Brand Corporations 2017. Retrieved from: https://www.europeanbrandinstitute.com/home/methoden/ (Access 20/10/2017) 
Fennell, Geraldine, Greg M Allenby, Sha Yang, and Yancy Edwards. (2003) The Effectiveness of Demographic and Psychographic Variables for Explaining Brand and Product Category Use." Quantitative Marketing and Economics 1: 223-244.

Fornell, C. \& Larcker, D.F. (1981) Evaluating structural equation models with unobservable variables and measurement error. Journal of Marketing Research, 18, 1, pp. 39-50

FutureBrand (2016) FutureBrand Index 2016. Retrived from: http://fbi.futurebrand.com/ (Access 20/10/2017)

Gecti, F. \& Zengin, H. (2013) The relationship between brand trust, brand affect, attitudinal loyalty and behavioral loyalty: A field study towards sports shoe consumers in turkey. International Journal of Marketing Studies, 5, 2, pp. 111-119.

González-Benito, O., Martos-Partal, M. \& Fustinoni-Venturini, M. (2015) Brand equity and store brand tiers: An analysis based on an experimental design. International Journal of Market Research, 57, 1, 73-94.

Hair, J. F. Jr., Black, W. C., Babin, B. J. \& Anderson, R. E. (2006) Multivariate Data Analysis: A global perspective (7th ed.). New Jersey: Pearson Education.

Han, S. H., Nguyen, B. \& Lee, T. J. (2015) Consumer-based chain restaurant brand equity, brand reputation, and brand trust. International Journal of Hospitality Management, 50, pp. 84-93.

Herstein, R., Gilboa, S. \& Gamliel, E. (2013) Private and national brand consumers' images of fashion stores. Journal of Product \& Brand Management, 22, 5/6, pp. 331-341.

Huang, R. \& Sarigöllü, E. (2014) Assessment of Brand Equity Measures. International Journal of Market Research, 56, 6, pp. 783-806.

Interbrand (2016) Best Global Brands 2016. Retrieved from: http://interbrand.com/bestbrands/best-global-brands/2016/ (Access 20/10/2017) 
Interbrand (2017) Best Global Brands 2017. Retrieved from: http://interbrand.com/bestbrands/best-global-brands/2017/ (Access 08/11/2017)

Izquierdo-Yusta, A., Labajo, V., Jiménez-Zarco, A. I. \& Martínez-Ruiz, M. P. (2016) Online Distribution Strategies: A Mix of Globalization and Diversification in the Fashion Market. In Handbook of Research on Strategic Retailing of Private Label Products in a Recovering Economy (pp. 491-512). Hershey PA: IGI Global.

Johansson, J. K., Dimofte, C. V. \& Mazvancheryl, S. K. (2012) The performance of global brands in the 2008 financial crisis: A test of two brand value measures. International Journal of Research in Marketing, 29, 3, pp. 235-245.

Kang, J., \& Hustvedt, G. (2014). Building trust between consumers and corporations: The role of consumer perceptions of transparency and social responsibility. Journal of Business Ethics, 125(2), 253-265.

Keller, K. L. (1993) Conceptualizing, Measuring, and Managing Customer-Based Brand Equity. Journal of Marketing, 57, January, pp. 1-22

Keller, K.L. (1998) Strategic brand management: Building, measuring, and managing brand equity. Upper Saddle River, New Jersey: Prentice Hall.

Khan, O., Christopher, M. \& Creazza, A. (2012) Aligning product design with the supply chain: a case study. Supply Chain Management: An International Journal, 17, 3, pp. 323-336.

Kim, G. J. (2014) Applying Service Profit Chain model to the Korean restaurant industry. International Journal of Hospitality Management, 36, 1-13.

Kuikka, A. \& Laukkanen, T. (2012) Brand loyalty and the role of hedonic value. Journal of Product \& Brand Management, 21, 7, pp. 529-537.

Kumar, V., Pozza, I. D. \& Ganesh, J. (2013) Revisiting the satisfaction-loyalty relationship: empirical generalizations and directions for future research. Journal of Retailing, 89, 3, pp. 246-262. 
L2 (2016) Digital IQ Index: Fashion 2016. Retrieved from: https://www.rankingthebrands.com/PDF/Digital\%20IQ\%20Index\%20Fashion\%20201 6,\%20L2\%20ThinkTank.pdf (Accessed 20/10/2017)

Lam, S. Y. \& Shankar, V. (2014) Asymmetries in the effects of drivers of brand loyalty between early and late adopters and across technology generations. Journal of Interactive Marketing, 28, 1, pp. 26-42.

Lassar, W., Mittal, B. \& Sharma, A. (1995) Measuring customer-based brand equity. Journal of Consumer Marketing, 12, 4, pp. 11-19.

Lee, J., Park, S. Y., Baek, I. \& Lee, C. S. (2008) The impact of the brand management system on brand performance in $\mathrm{B}-\mathrm{B}$ and $\mathrm{B}-\mathrm{C}$ environments. Industrial Marketing Management, 37, 7, pp. 848-855.

Luxton, S., Reid, M. \& Mavondo, F. (2015) Integrated marketing communication capability and brand performance. Journal of Advertising, 44, 1, pp. 37-46.

Malhotra, N. K. (2010) Marketing Research: An Applied Orientation, 6th ed. London: Pearson Education.

McColl, J. \& Moore, C. (2011) An exploration of fashion retailer own brand strategies. Journal of Fashion Marketing and Management: An International Journal, 15, 1, pp. 91-107.

Millward Brown (2014) BrandZ Top 100 most valuable global brand. Retrieved from: http://www.millwardbrown.com/docs/default-source/global-brandzdownloads/global/2014_BrandZ_Top100_Report.pdf (Accessed 20/10/2017)

Miquel-Romero, M. J., Caplliure-Giner, E. M. \& Adame-Sánchez, C. (2014) Relationship marketing management: Its importance in private label extension. Journal of Business Research, 67, 5, pp. 667-672.

Molinillo, S., Ekinci, Y. \& Japutra, A. (2015) A cross validation of Consumer-Based Brand Equity (CBBE) with Private Labels in Spain. In Martínez-López, Gázquez-Abad, J.C. 
\& Sethuraman, R. J.A. (Eds.) Advances in National Brand and Private Label Marketing (pp. 113-125). Second International Conference, Barcelona. Springer Proceedings in Business and Economics.

Molinillo, S., Ekinci, Y., Whyatt, G., Occhiocupo, N. \& Stone, M. (2016) Private Label Management: Insights and Research Directions. In Gómez-Suárez, M. \& MartínezRuiz, M. P. (Eds.) Handbook of Research on Strategic Retailing of Private Label Products in a Recovering Economy (pp. 1-27). Pennsylvania: IGI Global.

Morgan, C. (2004) Structure, speed and salience: performance measurement in the supply chain. Business Process Management Journal, 10, 5, pp. 522-536.

Nam, J., Ekinci, Y. \& Whyatt, G. (2011) Brand equity, brand loyalty and consumer satisfaction. Annals of Tourism Research, 38, 3, pp. 1009-1030.

Oliveira-Castro, J. M., Foxall, G. R., James, V. K., Pohl, R. H., Dias, M. B. \& Chang, S. W. (2008) Consumer-based brand equity and brand performance. The Service Industries Journal, 28, 4, pp. 445-461.

Oliver, R. L. (1999) Whence Consumer Loyalty? Journal of Marketing, 63, (Special Issue), pp. $33-44$.

Özsomer, A. \& Altaras, S. (2008) Global brand purchase likelihood: A critical synthesis and an integrated conceptual framework. Journal of International Marketing, 16, 4, pp. 1-28.

Phan, K. N. \& Ghantous, N. (2013) Managing brand associations to drive customers' trust and loyalty in Vietnamese banking. International Journal of Bank Marketing, 31, 6, pp. 456480.

Podsakoff, P. M., MacKenzie, S. B., Lee, J-Y. \& Podsakoff, N. P. (2003) Common Method Biases in Behavioral Research: A Critical Review of the Literature and Recommended Remedies. Journal of Applied Psychology, 88, 5, pp. 879-903. 
Romero, J. \& Yagüe, M. J. (2015) Relating brand equity and customer equity: An exploratory study. International Journal of Market Research, 57, 4, pp. 631-651.

Rust, R.T., Ambler, T., Carpenter, G.S., Kumar, V. \& Srivastava, R.K. (2004) Measuring marketing productivity: current knowledge and future directions. Journal of Marketing, 68, 4, 76-89.

Siegel Plus Gale (2017) Global Brand Simplicity Index 2017. Retrieved from: http://simplicityindex.com/ (Access 20/10/2017)

Simons, R. (2000) Performance Measurement and Control Systems for Implementing Strategy. Upper Saddle River, NJ: Prentice-Hall.

Spreng, R. A. \& Mackoy, R. D. (1996) An empirical examination of a model of perceived service quality and satisfaction. Journal of Retailing, 72, 2, pp. 201-214.

ter Braak, A., Geyskens, I. \& Dekimpe, M. G. (2014) Taking private labels upmarket: Empirical generalizations on category drivers of premium private label introductions. Journal of Retailing, 90, 2, 125-140.

The Harris Poll (2017) EquiTrend. Brand of the Year 2017. Retrieved from: http://www.theharrispoll.com/equitrend-rankings/2017_(Access 20/10/2017)

Tsai, H., Cheung, C. \& Lo, A. (2010) An exploratory study of the relationship between customer-based casino brand equity and firm performance. International journal of hospitality management, 29, 4, pp. 754-757.

Yoo, B. \& Donthu, N. (2001) Developing and validating a multidimensional consumer-based brand equity scale. Journal of Business Research, 52, 1, pp. 1-14.

Young \& Rubicam (2017) BrandAsset Valuator. How it works. Retrieved from: http://www.yr.com/bav_(Access 20/10/2017).

Zarantonello, L. \& Pauwels-Delassus, V. (2016) The handbook of brand management scales. Abingdon and New York: Routledge. 
Figure 1

The Consumer-Based Brand Performance Model (CBBPM)

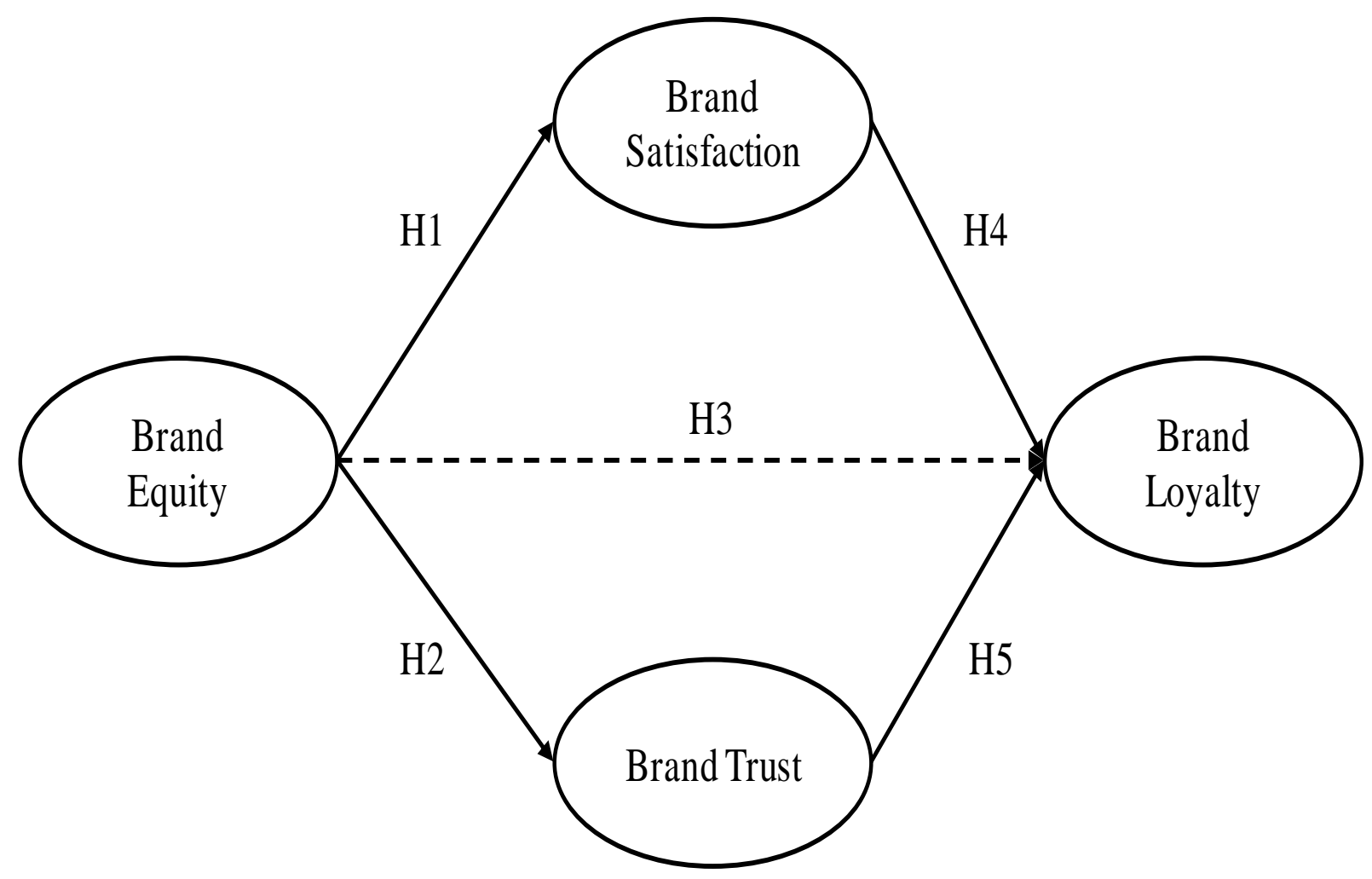

Note: $\longrightarrow$ Direct effect; - - $\rightarrow$ Indirect effect 
Table 1. Model Fit Statistics for the Measurement Models

\begin{tabular}{llllllllllc}
\hline & $\mathbf{N}$ & $\boldsymbol{\chi}^{\mathbf{2}}$ & df & $\boldsymbol{\chi}^{\mathbf{2} / \mathbf{d f}}$ & GFI & NFI & TLI & CFI & RMSEA & SRMR \\
\hline GBs & 435 & 212.10 & 84 & 2.53 & 0.94 & 0.96 & 0.97 & 0.97 & 0.06 & 0.04 \\
PLs & 446 & 189.75 & 84 & 2.26 & 0.95 & 0.94 & 0.96 & 0.97 & 0.05 & 0.04
\end{tabular}

Note: df: Degrees of freedom; GFI: Goodness of Fit Index; NFI: Normed Fit Index; TLI: Tucker Lewis Index; CFI: Comparative Fit Index; RMSEA: Root Mean Square Error of Approximation; SRMR: Standardised Root Mean Residual.

Table 2. Correlations, Reliability and Validity of the Measures

\begin{tabular}{llllll|lllll}
\hline \multicolumn{1}{c}{ GBs } & \multicolumn{5}{c}{ PLs } \\
\hline & $\boldsymbol{\alpha}$ & $\mathbf{1}$ & $\mathbf{2}$ & $\mathbf{3}$ & $\mathbf{4}$ & $\mathbf{A}$ & $\mathbf{1}$ & $\mathbf{2}$ & $\mathbf{3}$ & $\mathbf{4}$ \\
\hline $1 . \mathrm{BE}$ & 0.92 & $\mathbf{0 . 7 4}$ & 0.14 & 0.44 & 0.48 & 0.89 & $\mathbf{0 . 6 8}$ & 0.10 & 0.34 & 0.32 \\
2. BS & 0.93 & 0.38 & $\mathbf{0 . 7 3}$ & 0.22 & 0.30 & 0.84 & 0.31 & $\mathbf{0 . 5 2}$ & 0.19 & 0.38 \\
3. BT & 0.83 & 0.66 & 0.46 & $\mathbf{0 . 6 4}$ & 0.61 & 0.71 & 0.58 & 0.44 & $\mathbf{0 . 4 9}$ & 0.48 \\
4. BL & 0.78 & 0.69 & 0.55 & 0.78 & $\mathbf{0 . 5 9}$ & 0.69 & 0.56 & 0.62 & 0.69 & $\mathbf{0 . 5 4}$ \\
\hline
\end{tabular}

Note: BE: Brand Equity; BS: Brand Satisfaction; BT: Brand Trust; BL: Brand Loyalty; The diagonal values in bold indicate the average variances extracted (AVE). The scores in the lower diagonal indicate inter-construct correlations (IC). The scores in the upper diagonal indicate squared IC (SIC).

Table 3. Model Fit Statistics of the Structural Models

\begin{tabular}{llllllllllc}
\hline & $\mathbf{N}$ & $\boldsymbol{\chi}^{\mathbf{2}}$ & df & $\boldsymbol{\chi}^{\mathbf{2}} / \mathbf{d f}$ & GFI & NFI & TLI & CFI & RMSEA & SRMR \\
\hline GBs & 435 & 241.29 & 85 & 2.84 & 0.93 & 0.95 & 0.96 & 0.97 & 0.06 & 0.07 \\
PLs & 446 & 219.71 & 85 & 2.59 & 0.94 & 0.93 & 0.95 & 0.96 & 0.06 & 0.07
\end{tabular}

Note: df: Degrees of freedom; GFI: Goodness of Fit Index; NFI: Normed Fit Index; TLI: Tucker Lewis Index; CFI: Comparative Fit Index; RMSEA: Root Mean Square Error of Approximation; SRMR: Standardised Root Mean Residual. 
Table 4. Result of Structural Equation Analyses for the Research Model

\begin{tabular}{|c|c|c|c|c|c|c|c|c|c|c|c|c|c|}
\hline & \multirow{3}{*}{ Relationships } & \multirow{2}{*}{\multicolumn{2}{|c|}{$\begin{array}{c}\text { Global Brands } \\
\quad n=435\end{array}$}} & \multirow{2}{*}{\multicolumn{2}{|c|}{$\begin{array}{l}\text { Private Labels } \\
\quad n=446\end{array}$}} & \multicolumn{4}{|c|}{ Global Brands } & \multicolumn{4}{|c|}{ Private Labels } \\
\hline & & & & & & \multicolumn{2}{|c|}{$\begin{array}{c}\text { Sportswear } \\
\text { n= 230 }\end{array}$} & \multicolumn{2}{|c|}{$\begin{array}{c}\text { Apparel } \\
\mathbf{n}=205\end{array}$} & \multicolumn{2}{|c|}{$\begin{array}{c}\text { Sportswear } \\
\mathrm{n}=192\end{array}$} & \multicolumn{2}{|c|}{$\begin{array}{c}\text { Apparel } \\
\mathrm{n}=\mathbf{2 5 4}\end{array}$} \\
\hline & & $\overline{\text { SPC }}$ & t-value & SPC & t-value & SPC & t-value & SPC & t-value & SPC & t-value & SPC & t-value \\
\hline H1 & Brand Equity $\rightarrow$ Brand Satisfaction & 0.40 & $7.72^{* * * *}$ & 0.33 & $5.83^{* * *}$ & 0.42 & $5.79^{* * *}$ & 0.35 & $4.80^{* * * *}$ & 0.24 & $2.89^{* *}$ & 0.37 & $5.01^{* * * *}$ \\
\hline $\mathrm{H} 2$ & Brand Equity $\rightarrow$ Brand Trust & 0.67 & $11.04^{* * *}$ & 0.58 & $8.37^{* * *}$ & 0.72 & $8.15^{* * *}$ & 0.68 & $7.77^{* * *}$ & 0.57 & $5.38^{* * *}$ & 0.60 & $6.46^{* * *}$ \\
\hline $\mathrm{H} 3$ & Brand Equity $\rightarrow$ Brand Loyalty & 0.28 & $4.60^{* * * *}$ & 0.21 & $3.43^{* * * *}$ & 0.45 & $4.46^{* * *}$ & 0.22 & $2.65^{* *}$ & 0.19 & $1.81^{*}$ & 0.23 & $2.92^{* *}$ \\
\hline $\mathrm{H} 4$ & Brand Satisfaction $\rightarrow$ Brand Loyalty & 0.24 & $5.45^{* * *}$ & 0.41 & $5.13^{* * * *}$ & 0.27 & $4.49^{* * *}$ & 0.24 & $3.97^{* * *}$ & 0.36 & $2.85^{* *}$ & 0.44 & $5.26^{* * *}$ \\
\hline H5 & Brand Trust $\rightarrow$ Brand Loyalty & 0.49 & $7.03^{* * *}$ & 0.42 & $5.87^{* * *}$ & 0.31 & $3.35^{* * *}$ & 0.57 & $5.40^{* * *}$ & 0.46 & $2.74^{* *}$ & 0.39 & $4.15^{* * *}$ \\
\hline \multicolumn{14}{|c|}{ Variance explained $\left(\mathrm{R}^{2}\right)$} \\
\hline \multicolumn{2}{|c|}{ Brand Satisfaction } & \multicolumn{2}{|r|}{0.16} & \multicolumn{2}{|c|}{0.11} & \multicolumn{2}{|c|}{0.18} & \multicolumn{2}{|c|}{0.12} & \multicolumn{2}{|c|}{0.06} & \multicolumn{2}{|c|}{0.14} \\
\hline \multicolumn{2}{|c|}{ Brand Trust } & \multirow{2}{*}{\multicolumn{2}{|c|}{0.45}} & \multicolumn{2}{|c|}{0.34} & \multicolumn{2}{|c|}{0.52} & \multicolumn{2}{|c|}{0.46} & \multicolumn{2}{|c|}{0.32} & \multicolumn{2}{|c|}{0.36} \\
\hline \multicolumn{2}{|c|}{ Brand Loyalty } & & & \multicolumn{2}{|r|}{0.61} & \multicolumn{2}{|c|}{0.72} & \multicolumn{2}{|c|}{0.70} & \multicolumn{2}{|c|}{0.55} & \multicolumn{2}{|c|}{0.65} \\
\hline
\end{tabular}

Table 5. Mean Scores of Global Brands and Private Labels

\begin{tabular}{|c|c|c|c|c|c|c|c|c|c|c|c|c|c|c|c|}
\hline \multirow{3}{*}{$\begin{array}{l}\text { Brand Performance } \\
\text { Measures }\end{array}$} & \multirow{2}{*}{\multicolumn{2}{|c|}{$\begin{array}{l}\text { Global } \\
\text { Brands } \\
n=435\end{array}$}} & \multirow{2}{*}{\multicolumn{2}{|c|}{$\begin{array}{c}\text { Private } \\
\text { Labels } \\
n=446\end{array}$}} & \multirow{3}{*}{ t-value } & \multicolumn{4}{|c|}{ Global Brands } & \multirow{3}{*}{ t-value } & \multicolumn{4}{|c|}{ Private Labels } & \multirow{3}{*}{ t-value } \\
\hline & & & & & & \multicolumn{2}{|c|}{$\begin{array}{c}\text { Sportswear } \\
\mathbf{n}=\mathbf{2 3 0}\end{array}$} & \multicolumn{2}{|c|}{$\begin{array}{l}\text { Apparel } \\
\mathrm{n}=\mathbf{2 0 5}\end{array}$} & & \multicolumn{2}{|c|}{$\begin{array}{c}\text { Sportswear } \\
\mathrm{n}=192\end{array}$} & \multicolumn{2}{|c|}{$\begin{array}{c}\text { Apparel } \\
\text { n }=254\end{array}$} & \\
\hline & Mean & SD & Mean & SD & & Mean & SD & Mean & SD & & Mean & SD & Mean & SD & \\
\hline 1. Brand Equity & 3.95 & 1.62 & 4.21 & 1.44 & $2.53^{*}$ & 4.25 & 1.50 & 3.62 & 1.68 & $4.07^{* * * *}$ & 4.01 & 1.43 & 4.37 & 1.43 & $2.62^{* *}$ \\
\hline 2. Brand Satisfaction & 4.91 & 1.42 & 5.29 & 0.92 & $4.68^{* * *}$ & 5.02 & 1.34 & 4.79 & 1.50 & $1.69^{*}$ & 5.19 & 0.94 & 5.36 & 0.91 & $1.89^{*}$ \\
\hline 3. Brand Trust & 4.25 & 1.29 & 4.68 & 1.10 & $5.37^{* * *}$ & 4.21 & 1.24 & 4.29 & 1.34 & $0.62^{\text {n.s. }}$ & 4.69 & 1.07 & 4.68 & 1.13 & $0.14^{\text {n.s. }}$ \\
\hline 4. Brand Loyalty & 4.57 & 1.35 & 4.64 & 1.23 & $0.79^{\text {n.s. }}$ & 4.51 & 1.35 & 4.64 & 1.34 & $1.05^{\text {n.s. }}$ & 4.43 & 1.17 & 4.80 & 1.25 & $3.15^{* *}$ \\
\hline
\end{tabular}

Note: n.s.: not significant; ${ }^{*} p<.05 ;{ }^{* *} p<.01 ;{ }^{* * *} p<.001$. 